\title{
Focal Epithelial Hyperplasia
}

National Cancer Institute

\section{Source}

National Cancer Institute. Focal Epithelial Hyperplasia. NCI Thesaurus. Code C97083.

Hyperplasia characterized by the presence of a focal proliferation of epithelial cells. 